\title{
Occurrence of Zaprionus indianus (Diptera: Drosophilidae) in Agudo, Rio Grande do Sul, Brazil
}

\author{
Mauricio Paulo Batistella Pasini ${ }^{\bowtie}$ \& Dionísio Link
}

Universidade Federal de Santa Maria, e-mail: mauricio.pasini@gmail.com (Corresponding Author ${ }^{\bowtie}$ ), dlink@smail.ufsm.br.

EntomoBrasilis 5 (1): 70-74 (2012)

Abstract. This work has the first record of Zaprionus indianus Gupta (Diptera: Drosophilidae) found in the rural area of Agudo in the state of Rio Grande do Sul, Brazil. The adults were first found in plums (Prunus salicina Lindl). Subsequently it was found in mature figs (Ficus carica L.) in two orchards. In the first orchard about $80 \%$ of the collected figs were infested by $Z$. indianus. In the second orchard, $50 \%$ of the figs cv. "Pingo de mel" and 80\% of the figs of cv. "Roxo de Valinhos" were infested. On these collected figs a total of 1364 adult insects emerged. Figs of cultivar "Roxo de Valinhos" had higher adult emergence number. Besides being present in residues of the figs, Z. indianus was observed flying over debris from Syagrus romanzoffiana (Cham), Cucumis melo L., Citrullus vulgaris Schrad. and Vitis vinifera L., associated with other Drosophilidae. These findings indicate that measures for monitoring and pest control should be adopted in the county to ensure high quality figs.

Keywords: Abundance; Ficus carica; Fig fly; Preference.

\section{Ocorrência de Zaprionus indianus (Diptera: Drosophilidae) em Agudo, Rio Grande do Sul, Brasil}

Resumo. Este trabalho faz menção ao primeiro registro de Zaprionus indianus Gupta (Diptera: Drosophilidae) encontrado na zona rural do município de Agudo, no estado do Rio Grande do Sul, Brasil. Os adultos da mosca foram encontrados primeiramente em frutos de ameixa (Prunus salicina Lindl) posteriormente em figos maduros (Ficus carica L.) em dois pomares. No primeiro pomar cerca de 80\% dos figos coletados apresentaram ataque de $Z$. indianus e, no segundo pomar 50\% dos figos da cv. "Pingo de mel" e 80\% da variedade "Roxo de Valinhos" foram infestados. No período correspondente a emergência dos adultos, coletou-se um total de 1364 indivíduos. Os figos da cv "Roxo de Valinhos" apresentaram maior emergência de adultos. Além de estar presente em restos culturais de figo, $Z$. indianus foi visualizada sobrevoando restos culturais de Syagrus romanzoffiana (Cham.), Cucumis melo L., Citrullus vulgaris Schrad. e Vitis vinifera L., associada a outros drosofilídeos. Ressalta-se que medidas de monitoramento e controle da praga deverão ser adotadas no município para garantir figos de alta qualidade e sadios.

Palavras-Chave: Abundância; Ficus carica; Mosca do figo; Preferência.

This work intends to report the first record of Zaprionus indianus Gupta, in Agudo county, located in the central region of Rio Grande do Sul state (RS), Brazil, wich it is not characterized at the national or regional levels, as an important fig producer. The existing orchards are of small size, with figs destined for raw consumption, as well as in production of sweet pastes, jams, and confectioneries (pies and cakes).

The first record of $Z$. indianus in the American continent was observed on rotting persimmon fruits (Diospyros kaki L.) in the city of Santa Isabel, São Paulo (VIlela 1999). Later, it was also observed attacking fig fruits (Ficus carica L. cv. "Roxo de Valinhos") at the early maturing stage in the municipality of Valinhos, São Paulo (VILELA et al. 2000). Gradually, observations were made in other states such as Minas Gerais (KAто et al. 2004), Santa Catarina (DE Toni et al. 2001) and Rio Grande do Sul, in the coastal city of Porto Alegre (Silva et al. 2005). In the American continent, registrations were performed in Uruguay (GoÑ et al. 2001), Panama, United States (VAN Der Linde et al. 2006) and Argentina (LAVAGNino et al. 2008).

The fly has a short development period whereby lays its eggs on the fig ostiole, and the larvae penetrate the fruits, rendering them unfit for consumption. This point of entry creates vulnerability for the fruits to then be infected with the fungus Candida tropicalis Berkhout, leading to produce significant losses of figs (VILELA et al. 2000; Gomes et al. 2003). Losses have been estimated at $40 \%$ in "fresh" figs and 80\% reduction in fruits eligible for export (STEIN et al. 2003).

In Agudo County (RS), adults of $Z$. indianus were observed flying above decomposing cultural remains of plum trees (Prunus salicina Lindl). Adults were later found in figs ( $F$. carica) in two orchards in that same county. The first home orchard (P1) had the variety "Roxo de Valinhos", with three plants. The second orchard (P2) had two cultivars of figs, "Roxo de Valinhos", with seven plants, and "Pingo de mel", with three plants. The distance between the orchards was about five kilometers.

On January, 30, 2011 after detecting Z. indianus in those orchards, figs damaged by birds, attacked by Dermestidae (Coleoptera) as well as and figs lying on the ground, were collected. In the first orchard, 12 figs were collected and in the second 45 figs ( 25 "Roxo de Valinhos" and 20 "Pingo de mel"). The fruits were placed individually into sealed one-liter pots and taken to cool place under sunlight. The pots were examined every week until no more adult specimens emerged. In each test the emerged adults were removed from pots, identified, sexed, and inventoried. 
The adult emergence covered the period from February 6 to February 27, 2011. Throughout the period there was no observed emergence of the hymenoptera parasitoids known to attack $Z$. indiamus (MARChIORI et al. 2003; Marchiori \& Silva 2003; Silva et al. 2004). In the first orchard, $83 \%$ of fruits collected were infested by $Z$. indianus. In the second, $50 \%$ of "Pingo de mel" and $80 \%$ of "Roxo de Valinhos" presented infestation.

From the infested figs, 1364 adults were obtained, 609 males and 755 females. Of these, 323 adults were from the first orchard and 1041 were from the second orchard. The average adult emergence rate in individual fruits by orchards were similar, being $32.3( \pm$ 14.33) adults per fruit, $15( \pm 6.7)$ males and $17.3( \pm 7.8)$ females in $\mathrm{P} 1$ and $34,02( \pm 16.03)$ adults, $15.03( \pm 6.99)$ males and 19 ( \pm 9.99) females in P2 (Table 1). In the cv. "Roxo de Valinhos" figs, fruits presented a higher average emergence of adults per fruit compared with the cv. "Pingo de mel" specifically, 42.35 ( \pm $12.39), 18.45$ ( \pm 5.42$)$ males and $23.9( \pm 8.3)$ females emerged from the first, opposed to $19.4( \pm 11.34), 9( \pm 5.51)$ males and 10.4 $( \pm 6.75)$ females that emerged from the second (Figure 1). The largest number of adults was observed in the second week after fig harvest. The cv. "Pingo de mel" showed higher emergence in the third week after fruit gathering (Figure 2).

Besides being present in fig residues, $Z$. indianus was observed flying over cultural debris from Syagrus romanzoffiana (Cham.), Cucumis melo L., Citrullus vulgaris Schrad. and Vitis vinifera L., fruits associated with other Drosophilidae. These findings indicate that measures for monitoring and pest control should be adopted in the county to ensure a high quality of the figs produced.

\section{REFERENCES}

De Toni, D.C., P.R.P. Hofmann \& V.L.S. Valente, 2002. First register of Zaprionus indianus (Diptera: Drosophilidae) in the state of Santa Catarina. Biotemas, 14:71-85.

Gomes, L.H., S. Echeverrigaray, J.H. Conti, M.V.M. Lourenço \& K.M.R Duarte, 2003. Presence of the yeast Candida tropicalis in figs infected by the fruit fly Zaprionus indianus (Dip.: Drosophilidae). Brazilian Journal of Microbiology, 34: 5-7.

Goñi, B., P. Fresia, M. Calviaño, M.J. Ferreiro, V.S.L. Valente \& B. Silva, 2001. First record of Zaprionus indianus Gupta, 1970 (Diptera: Drosophilidae) in southern localities of Uruguay. Drosophila Information Service, 84: 61-65.

Kato, C.M., L.V. Foureaux, R.A. César \& M.P. Torres, 2004. Ocorrência de Zaprionus indianus Gupta, 1970 (Diptera: Drosophilidae) no Estado de Minas Gerais. Ciência e agrotecnologia, 28: 454-455.

Lavagnino, N.J., V.P. Carreira, J. Menesch, E. Hasson \& J.J. Fanara, 2008. Geographic distribution and hosts of Zaprionus indianus (Diptera: Drosophilidae) in NorthEastern Argentina. Revista de la Sociedad Entomológica Argentina, 67: 189-192.

Van Der Linde, K., G.J. Steck, K. Hibbard, J.S. Birdsley, L.M. Alonso \& D. Houle, 2006. First records of Zaprionus Indianus (Diptera: Drosophilidae), a pest species on commercial fruits from Panama and The United States of America. Florida Entomologist, 89: 402-404.

Table 1. Emerged adults of Zaprionus indianus in two orchards in the county of Agudo Caunty, RS, Brazil, 2011.

\begin{tabular}{|c|c|c|c|c|c|c|c|c|}
\hline \multirow{2}{*}{ Orchard } & \multirow{2}{*}{$\mathbf{c v}^{3}$} & \multirow{2}{*}{$\mathbf{n}^{4}$} & \multicolumn{3}{|c|}{ Adults captured } & \multirow{2}{*}{$x^{8}$} & \multirow{2}{*}{ SD $^{9}$} & \multirow[b]{2}{*}{$\mathbf{C V}^{10}$} \\
\hline & & & $\delta^{5}$ & $q^{6}$ & $\Sigma^{7}$ & & & \\
\hline $1^{1}$ & "Roxo de Valinhos" & 10 & 150 & 173 & 323 & 32,3 & 14,32 & 0,44 \\
\hline \multirow{2}{*}{$2^{2}$} & "Roxo de Valinhos" & 20 & 369 & 478 & 847 & 42,35 & 12,38 & 0,29 \\
\hline & "Pingo de mel" & 10 & 90 & 104 & 194 & 19,4 & 11,33 & 0,58 \\
\hline & $1+2$ & 40 & 609 & 755 & 1364 & 34,1 & 15,58 & 0,45 \\
\hline
\end{tabular}

captured; ${ }^{8}$ arithmetic mean; ${ }^{9} \mathrm{dp}-$ Standard Deviation; ${ }^{10} \mathrm{CV}-$ coefficient of variation.

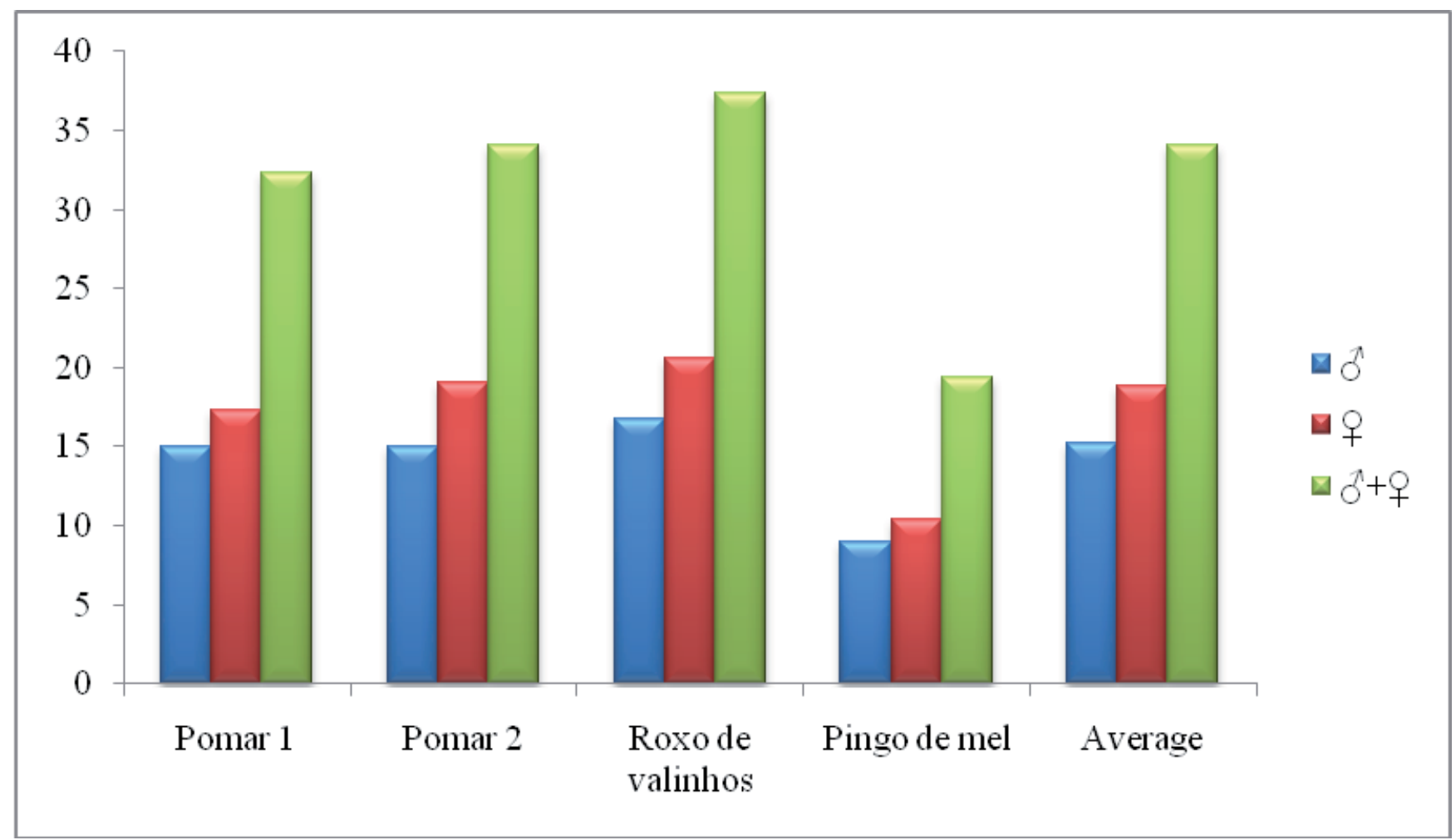

Figure 1. Average number of adults of $Z$. indianus (males, females, and males + females) emerged from figs cv. "Roxo de Valinhos" and cv. "Pingo de mel" in two locations of Agudo county, RS, Brazil, 2011. 


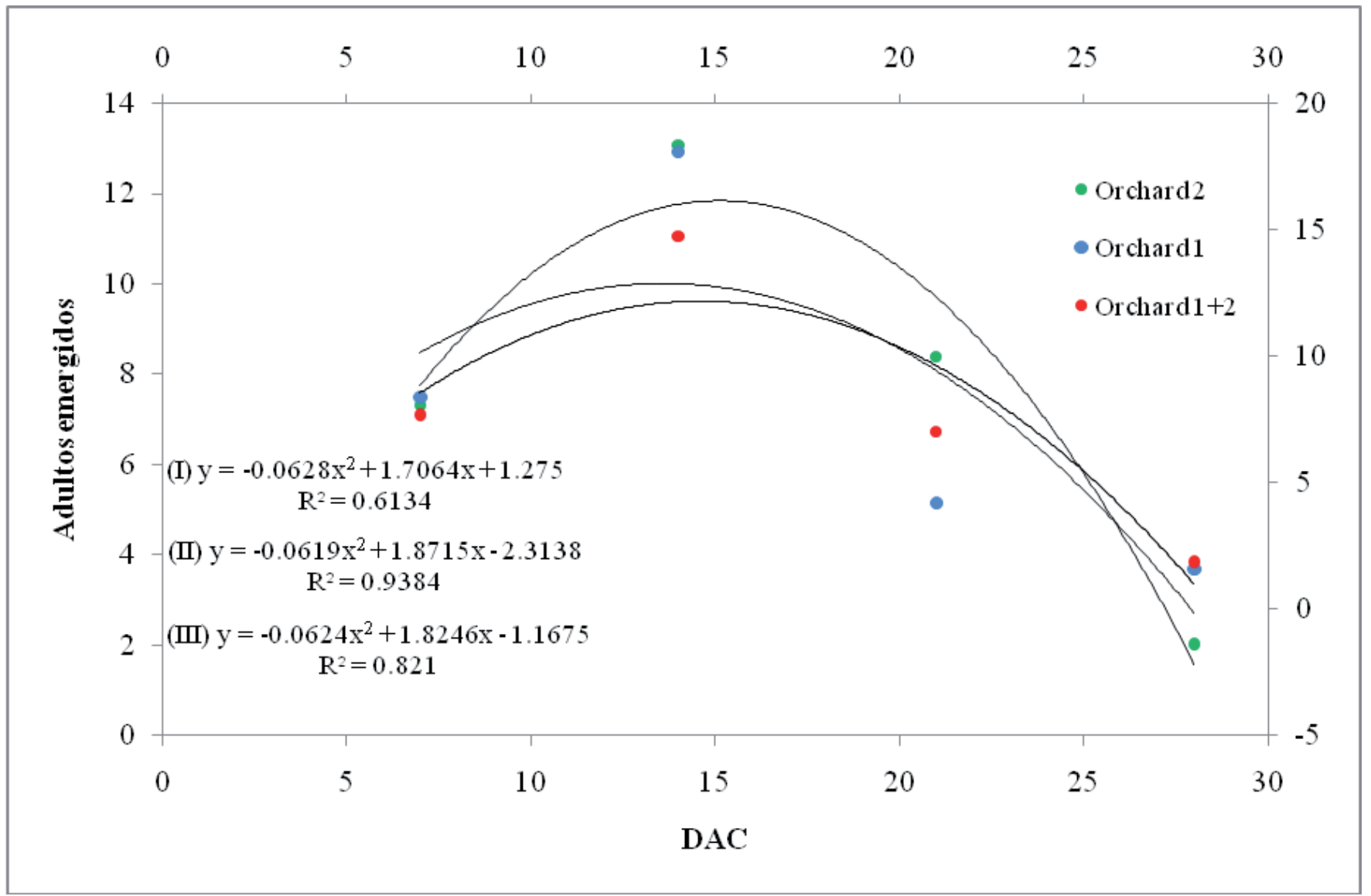

Figure 2. Adults emerged of $Z$. indianus in different days after collection of figs (DAC) in Agudo, RS, Brazil, 2011. (I) Orchard 1; (II) Orchard 2; (III) Orchard $1+2$.

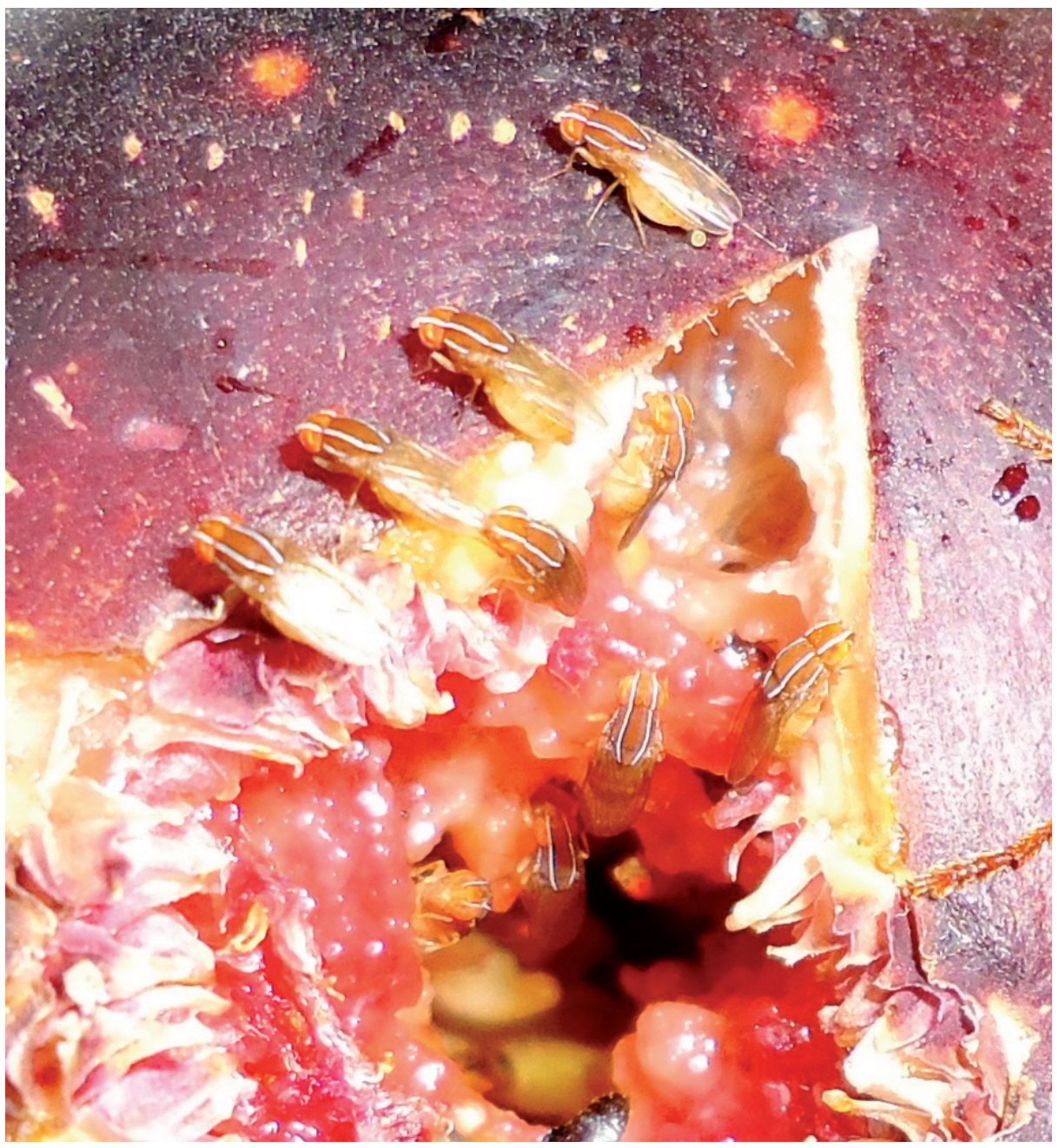

Figure 3. Z. indianus incidence in fig cv. "Roxo de Valinhos" in Agudo Caunty, RS, Brazil, 2011. (Foto: Mauricio Pasini) 


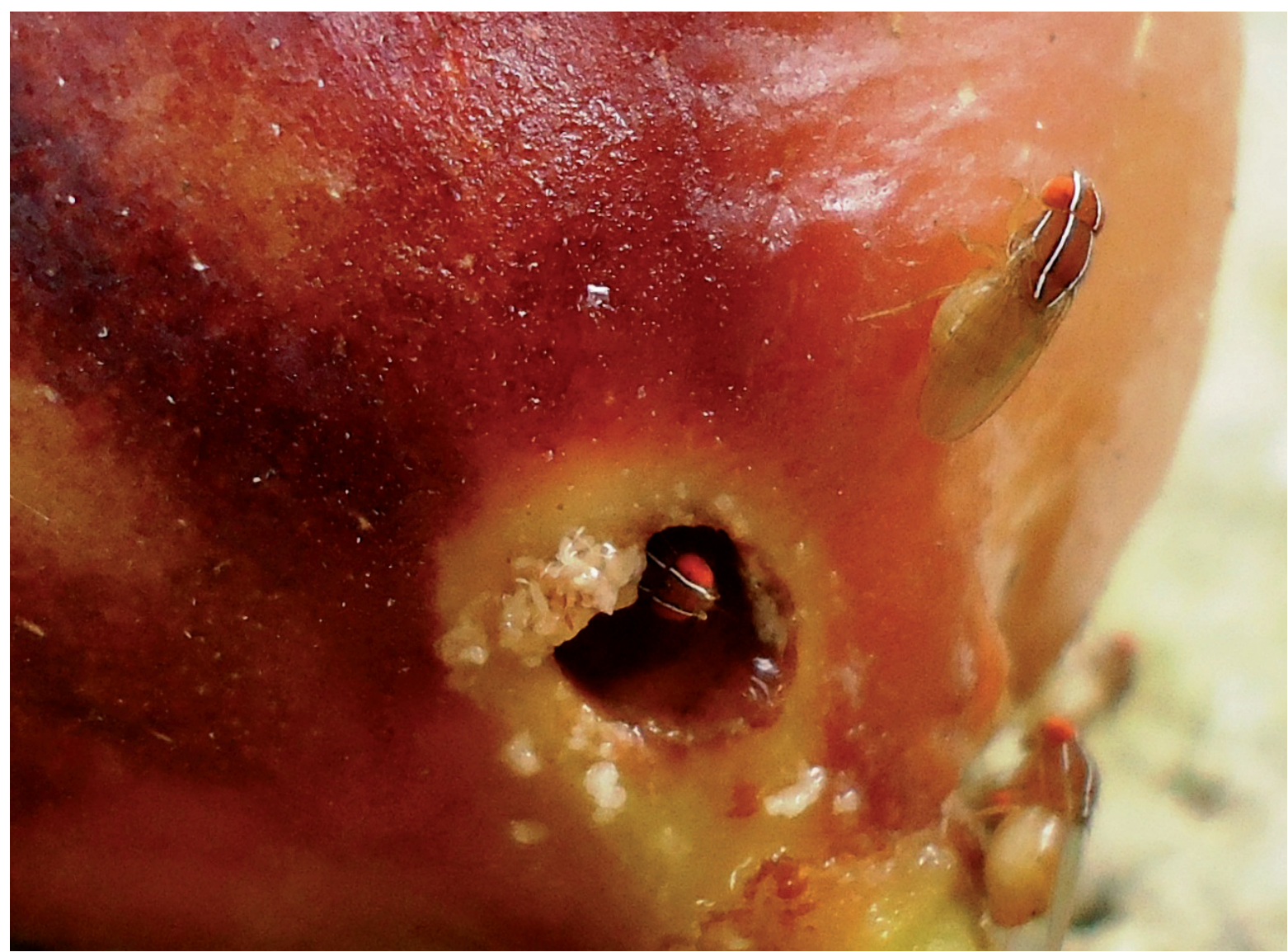

Figure 4. Z. indianus in fig cv. "Roxo de Valinhos" with hole caused by Dermestidae (Coleoptera) in Agudo Caunty, RS, Brazil, 2011. (Foto: Mauricio Pasini)

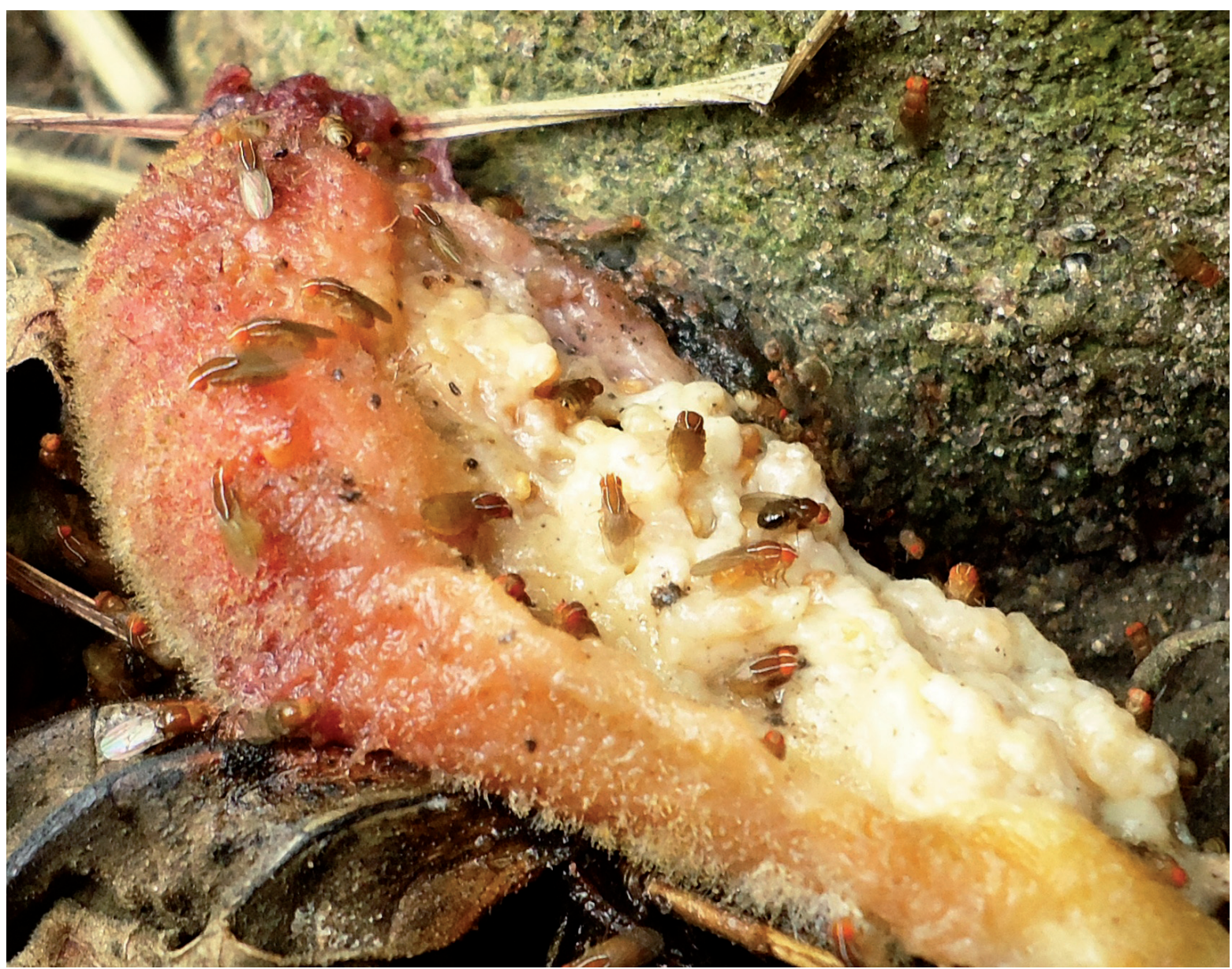

Figure 5. Occurence of $Z$. indianus with any other drosophilids, using this substrate for food and oviposition in Agudo Caunty, RS, Brazil, 2011. (Foto: Mauricio Pasini) 
Marchiori C.H., S.B. Arantes, L.A. Pereira, O.M. Silva Filho \& V.R. Borges, 2003. First Record of Leptopilina boulardi Barlotin et al. (Hymenoptera: Figitidae: Eucoilinae) parasiting of Zaprionus indianus Gupta (Diptera: Drosophilidae) in Brazil. Semina: Ciências Agrárias, 24: 321-324.

Marchiori, C.H. \& C.G. Silva, 2003. First occurrence of parasitoid Spalangia endius (Walker) (Hymenoptera: Pteromalidae) in pupae of Zaprionus indianus Gupta (Diptera: Drosophilidae) in Brazil. Brazilian Journal Biology, 63: 361-362.

Silva, C.G., R.I.F. Costa, C.H. Marchiori, L.C. Torres \& B.B. Amaral, 2004. Ocorrência de Pachycrepoideus vindemiae (Rondani, 1875) (Hym.: Pteromalidae) em pupas de Zaprionus indianus Gupta (Dip.: Drosophilidae) coletados em frutos de goiaba. Arquivos do Instituto Biológico, 1: 91-92.

Silva, N.M., C.C. Fantinel, V.L. Valente \& V.H. Valiati, 2005. Ecology of colonizing of the fig fly Zaprionus indianus
(Diptera: Drosophilidae) in Porto Alegre, Southern Brazil. Iheringia, Série Zoológica, 95: 233-240.

Stein, C.P., E.P. Teixeira \& J.P.S. Novo, 2003. Aspectos biológicos da mosca do figo, Zaprionus indianus Gupta, 1970 (Diptera: Drosophilidae). Entomotropica, 18: 219-221.

Vilela C.R., 1999. Is Zaprionus inaidnus Grupta, 1970 (Diptera, Drosophilidae) currently colonizing the Neotropical Region? Drosophila Information Service, 82:48-52.

Vilela, C.R., E.P. Teixeira \& C.P. Stein, 2000. Mosca-Africanado-figo, Zaprionus indianus (Diptera: Drosophilidae), p. 48-52. In: Vilela, E.F., Zuchi, R.A. \& F. Cantor (Eds.). Pragas Introduzidas no Brasil. Ribeirão Preto: Holos, 179p.

\section{Recebido em: 16/05/2011 \\ Aceito em: 17/o1/2012}

\section{Como citar este artigo:}

Pasini, M.P.B \& D. Link, 2012. Occurrence of Zaprionus indianus (Diptera: Drosophilidae) in Agudo, Rio Grande do Sul, Brazil. EntomoBrasilis, 5(1): 70-74.

Acessível em: http://www.periodico.ebras.bio.br/ojs/index.php/ebras/article/view/142
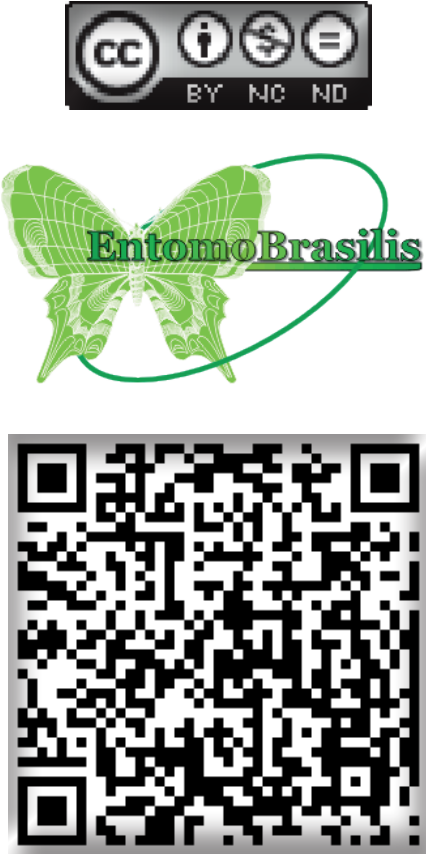